Social Work with Psychiatric Patients 


\title{
Social Work with Psychiatric Patients
}

\author{
Barbara L. Hudson
}

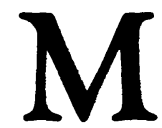

MACMILLAN 


\section{() Barbara L. Hudson 1982}

All rights reserved. No reproduction, copy or transmission of this publication may be made without written permission.

No paragraph of this publication may be reproduced, copied or transmitted save with written permission or in accordance with the provisions of the Copyright Act 1956 (as amended), or under the terms of any licence permitting limited copying issued by the Copyright Licensing Agency, 33-4 Alfred Place, London WC1E 7DP.

Any person who does any unauthorised act in relation to this publication may be liable to criminal prosecution and civil claims for damages.

First published 1982

Reprinted 1985, 1987, 1989

Published by

MACMILLAN EDUCATION LTD

Houndmills, Basingstoke, Hampshire RG21 2XS

and London

Companies and representatives

throughout the world

ISBN 978-0-333-26686-1

DOI 10.1007/978-1-349-16788-3

ISBN 978-1-349-16788-3 (eBook) 
To my parents, Lorentz and Lorna Gullachsen 


\section{Contents}

Preface ix

Acknowledgements xii

1 Introduction: Psychiatry and Social Work - Contention and Co-operation

\section{Part 1 Psychiatric Disorders}

2 Schizophrenia

3 Hypomania and Severe Depressive Illness (The Affective Psychoses)

4 Psychological and Social Approaches to Depression

5 Anxiety States and Phobias

6 Other Neurotic Disorders 58

7 Personality Disorders 68

8 Problem Drinking and Drug Abuse 78

9 Organic Disorders with Special Reference to the Elderly 91

\section{Part 2 General Issues}

10 The Children of the Psychiatric Patient 109

11 Work and Money 123

12 Accommodation 136

13 Psychiatric Emergencies, Hospital Admission and Crisis Intervention 
viii Contents

14 Social Work in Hospital 166

15 Concluding Remarks: Research and Recording 172

Appendix A: Suggestions for Further Reading $\quad 181$

Appendix B: Glossary $\quad 185$

Bibliography $\quad 189$

Author Index 207

Subject Index $\quad 212$ 


\section{Preface}

This book is about people who come under the care of a psychiatrist and about practical ways of helping them and their families. I have not set out to write a psychiatry textbook, nor to review the important sociological and philosophical issues that have figured prominently in the literature of the social work profession in recent years.

One study in a British social services department concluded that the social workers' involvement with the mentally ill was minimal: 'On the whole, the impression was gained that the social workers were holding a watching brief unless a crisis forced them to arrange the care of children or admission to hospital of adult clients' (Goldberg and Warburton, 1979). Other commentators are more critical: 'The social work role in relation to the mentally ill client has in most local authorities become stagnant, and the emphasis has remained upon outdated methods of intervention which has led to the atrophy of skill development' (Goldberg and Huxley, 1980). The low priority given to this client group may be related not only to shortage of resources but also to lack of specialised knowledge. This book is an attempt to go some way towards remedying this lack, and to offer suggestions for further study of mental disorder and how sufferers might be helped.

Several chapters focus on specific (and not so specific) diagnoses of mainstream psychiatry. Some social workers may find this objectionable. But an understanding of the language of psychiatry - how psychiatrists use terms like 'schizophrenia' or 'dementia' - is a sine qua non for mutually intelligible communication; and, moreover, research findings concerning some at least of the diagnostic groups do offer guidelines - working hypotheses - as to how we might begin to assist the individual and those around him. Several common 
disorders are described, 'from the outside', as it were; an attempt is made to convey something of the patient's and the family's experience; and common treatment approaches are outlined. I seek to draw conclusions about possible social work intervention from two main sources: from accounts and evaluations of treatment; and from the knowledge we have about psycho-social factors implicated in the course of each disorder - factors that may increase the likelihood of relapse, contribute to distress and disability, or intensify the burden on the family. Care is taken to distinguish between statements based only on experience and unsystematic observation, and statements based on empirical research. While my emphasis is on the latter, there are many areas where little is known, and others where what is known does not lead one to regard social work as having a major role in the helping process. For these reasons, the length of the sections is uneven - some topics get many pages, others a few lines. The chapters are not intended to be read in isolation: much of what is said about intervention in relation to one condition can apply to others.

The second part of the book deals with some general issues: the children of the psychiatric patient; accommodation, work and money problems; and aspects of social work in emergency situations and in the hospital setting.

If one can conceptualise mental disorder as a continuum ranging from the mild to the severe, then it is the severe end that is highlighted. Among many omissions, the reader will note that I have not covered child psychiatry, mental handicap or forensic psychiatry, and have mentioned only in passing special settings such as the therapeutic community and problems such as sexual dysfunction and marital discord, which often come to the attention of psychiatrists but do not in themselves constitute mental disorder. Each of these topics has its own specialist literature, whereas the literature of 'bread-and-butter' psychiatric social work is sparse.

There is a bias towards behavioural approaches. Apart from the fact that my own reading of the evidence suggests that this is a fruitful area in which social work can develop, I feel that this emphasis is justified on the grounds that psychodynamic approaches are adequately covered in other social work textbooks and that most social workers are already equipped to apply them when it seems appropriate to do so.

A central problem in writing this book has been how to depict the 
typical social worker. I cannot pretend to have solved it. I have drawn on personal experience and the descriptions of social work with psychiatric patients given in several research reports. The resulting composite picture is immodest, to say the least. My prototype possesses a wide range of skills and knowledge; he can do casework and groupwork according to a variety of different models; he is an administrator and a planner; he is a political campaigner; and his education has prepared him to read critically, to be articulate, and to be able to conceptualise his work and generalise appropriately from his experience. He is knowledgeable about psychology, sociology and social policy. And in addition to all this, I am suggesting that he can develop specialised skills for work in the psychiatric services!

I am aware that many, if not all, of the roles I suggest can be and are filled by other professional workers. The new profession of community psychiatric nursing has already added to basic nursing skills and knowledge much of the expertise that social work has traditionally considered to be its own province. Community psychiatry and community psychology have moved in a similar direction. Some observers have suggested that social work is being replaced with regard to the care of the mentally disordered in Britain; but, at the same time, there seems to be a renewed interest among social workers in this client group and in further training courses teaching specialist skills. In the USA, on the other hand, social workers appear to be undertaking a variety of innovative and responsible roles in the psychiatric services.

It is impossible to guess how far such trends are likely to go. The main purpose of this book is to help social workers with the task of applying their generic skills to the special problems of the mentally disordered in co-operation with other workers in the psychiatric services, and I believe this will continue to be important in the foreseeable future. 


\section{Acknowledgements}

Jane Stainer read the whole manuscript. Individual chapters were read by Biddy Andrew, Vera Baraniecka, Rosemary Fitzgerald, Monica Greenwood, Roger McAuley, Pauline McDonnell, David Millard, Rolf Olsen, Brian Sheldon, Richard Stern and Kathy Sylva. They all helped me a great deal, and I am extremely grateful. Any errors, omissions and biases that remain are my own.

Brenda Dry typed and retyped with extraordinary patience and skill.

Steven Kennedy of the Macmillan Press Ltd provided effective reinforcement, both positive and negative.

B. L. H. 